\title{
Regulatory and Methodological Changes in the System of Higher Education Quality Assurance
}

\author{
Svetlana Efimovna Starostina1 \\ Natalia Anatolyevna Kazachek² \\ ${ }^{1}$ Transbaikal State University, Chita, Russian Federation \\ ${ }^{2}$ Transbaikal State University, Chita, Russian Federation \\ Email: sestarost@mail.ru
}

Doi:10.5901/mjss.2015.v6n4s4p140

\begin{abstract}
The year 2015 can be considered the year of the regulatory and methodological changes in the system of higher education quality assurance. There are plans to bring into effect new standards governing the education quality assurance, both at the global and national levels. Also, the enforcement of new standards and guidelines for quality assurance in the European Higher Education Area is expected, and the international standard ISO 9001:2015 "Quality Management Systems. Requirements" is being developed. A number of regulations have been put in effect at the national level: the Concept of the federal targeted program of education development for 2016-2020, the Order of the Ministry of Education of the Russian Federation "On approval of the indicators characterizing the general criteria for assessing the quality of the educational activities of organizations engaged in the educational activities," federal state educational standards of higher education, which make adjustments to the federal state educational standards of higher professional education-the so-called third-generation standards. In 2014, the activities of the Transbaikal State University were focused on the upcoming changes. The university developed a system of education quality assurance. The present article describes the operation of the in-house education quality assurance system that conforms to the European standards and national regulations and guidelines.
\end{abstract}

Keywords: quality, higher education, education quality assurance, quality assessment, standard.

\section{Introduction}

The year 2015 is becoming a landmark year in the legislative and methodological regulation of higher education quality assurance at the global and national levels. In 2015, we expect the enactment of new standards and guidelines for quality assurance in the European Higher Education Area (ESG ENQA), which will result in changes in the criteria for professional public accreditation in the Russian Federation, as they are based on ESG ENQA (The criteria and procedure for professional and public accreditation of technical educational programs, 2013). The issues of changes in the standards and guidelines were discussed at the IX International Forum of the Experts' Guild "The Integration of European Standards and Guidelines in the Education Quality Assurance Systems" (Bagrov, 2014; Laushkin, 2014; Matveeva, 2014; Yanov, 2014).

In 2015, the international standard ISO 9001:2015 "Quality Management System. Requirements" is going to be put into effect. This will have a certain effect on education, since many Russian educational organizations build their quality management systems based on ISO standards (Kazachek, 2012).

The problems of quality and its assessment are the key ones in today's educational environment (Gorbashko, Gidrovich and Egorova, 2004; Pokholkov, Chuchalin, Boev and Mogilnitsky, 2004; Assad, 1995; Juran, 1993; Quality Procedures in European Higher Education, 2003). Increasing attention is paid to these issues in the field of education in Russia, resulting in the approval of new regulatory and methodological instruments in this area. These include: The Concept of the federal target program of education development for 2016-2020, the Order of the Ministry of Education of the Russian Federation "On approval of the indicators characterizing the general criteria for assessing the quality of the educational activities of organizations engaged in the educational activities, and federal state educational standards of higher education.

The article provides an analysis of the above documents, focusing on the peculiarities affecting the activities of higher educational institutions, and describes the activity of the Transbaikal State University in 2014, focused on the upcoming changes. 


\section{Methodology and Results}

The results of the university's activity in 2014 were analyzed using a strategic planning method-the SWOT-analysis. The strengths and weaknesses of the university, its external opportunities and threats were analyzed. Then we considered the implementation of the opportunities using the strengths, the neutralization of threats using the strengths, and the overcoming of weaknesses and threats using the favorable opportunities (Kelsey, 1999; Review of the principles of formation of in-house systems of education quality, 2013).

The organization of operation of a higher educational institution is particularly dependent on the changes in the standards and guidelines for in-house quality assurance ESG ENQA (Standards and guidelines for quality assurance in the European Higher Education Area, 2008; Standards and guidelines for quality assurance in the European Higher Education Area, 2005). The names of the standards and their content change and new standards appear. A comparative analysis of the adopted standards and guidelines for in-house quality assurance with the current version is provided in the table (Standards and guidelines for quality assurance in the European Higher Education Area, 2014) (Table 1).

Table 1. The comparative analysis of ESG ENQA of 2005 and 2015

\begin{tabular}{|c|c|c|c|}
\hline \multirow{2}{*}{\begin{tabular}{|l|l} 
Sq. \\
No.
\end{tabular}} & \multicolumn{2}{|c|}{ The standard description } & \multirow{2}{*}{ Comments to the content of the new version of standards and guidelines } \\
\hline & 2005 & 2015 & \\
\hline 1 & $\begin{array}{l}\text { Quality assurance policy } \\
\text { and procedures }\end{array}$ & Quality assurance policy & $\begin{array}{l}\text { In-house stakeholders should develop and implement the policy of the organization using } \\
\text { appropriate structures and processes and involving external stakeholders. It is } \\
\text { emphasized that the policy must concern the activities of subcontractors and partners }\end{array}$ \\
\hline 2 & $\begin{array}{l}\text { Approval, monitoring, and } \\
\text { periodic assessment of } \\
\text { programs and } \\
\text { qualifications }\end{array}$ & $\begin{array}{l}\text { Development and approval } \\
\text { of programs }\end{array}$ & $\begin{array}{l}\text { Monitoring and periodic assessment have been moved to a separate standard 1.9. } \\
\text { The standard refers to the conformance to the national qualification framework. The } \\
\text { attention is focused on the independence of the program approval procedure, which } \\
\text { must be carried out by persons and bodies that are not involved in the development of } \\
\text { the program or its delivery. }\end{array}$ \\
\hline 3 & $\begin{array}{l}\text { Assessment of the level of } \\
\text { students' knowledge. }\end{array}$ & $\begin{array}{l}\text { Student-centered learning } \\
\text { and assessment. }\end{array}$ & $\begin{array}{l}\text { The standard has been expanded. The need for student-centered learning organization } \\
\text { has been introduced. The document has relevant recommendations formulated }\end{array}$ \\
\hline 4 & - & $\begin{array}{l}\text { Reception, performance, } \\
\text { recognition, and certification }\end{array}$ & $\begin{array}{l}\text { A new standard has been enacted. A higher educational institution must determine, } \\
\text { document, publish, and consistently apply the procedures at all stages of the so-called } \\
\text { "student life cycle" from enrollment to graduation }\end{array}$ \\
\hline 5 & $\begin{array}{l}\text { Assurance of quality and } \\
\text { competence of the faculty }\end{array}$ & Faculty & $\begin{array}{l}\text { The provided recommendations refer to changing the role of the teacher in connection } \\
\text { with the implementation of the student-centered approach to learning. New } \\
\text { recommendations on the incentives for the scientific activity of the faculty to use } \\
\text { innovative teaching methods have appeared }\end{array}$ \\
\hline 6 & $\begin{array}{l}\text { Educational resources } \\
\text { and the student support } \\
\text { system }\end{array}$ & $\begin{array}{l}\text { Educational resources and } \\
\text { the student support system }\end{array}$ & $\begin{array}{l}\text { An indication of the mechanism to provide resources and systems for the students' } \\
\text { support-the creation of specialized support services for students-has been included in } \\
\text { the standards and guidelines. New recommendations on the needs of different groups of } \\
\text { students (adults, working, external, foreign students, and students with disabilities) has } \\
\text { appeared. It is also recommended to take into account the trends of student-centered } \\
\text { training }\end{array}$ \\
\hline 7 & Awareness system & Information Management & $\begin{array}{l}\text { The } 2005 \text { standard said about creating a system of collection, analysis, dissemination, } \\
\text { and use of information about the university's own activities. The guidelines describe the } \\
\text { self-examination procedure. } \\
\text { The } 2015 \text { standard focuses on the management of information provided the system of } \\
\text { collection, analysis, dissemination, and use of information has already been established. } \\
\text { A higher educational institution is to ensure the availability of such a system }\end{array}$ \\
\hline 8 & Public awareness & Public awareness & $\begin{array}{l}\text { The recommendation is that the information should be accurate, objective, and } \\
\text { accessible; it becomes a part of the standard }\end{array}$ \\
\hline 9 & - & $\begin{array}{l}\text { Continuous monitoring and } \\
\text { periodic assessment of } \\
\text { programs }\end{array}$ & Creating a new standard is determined by the particular importance of this activity \\
\hline 10 & - & $\begin{array}{l}\text { Periodic procedures of } \\
\text { external quality assurance }\end{array}$ & $\begin{array}{l}\text { A new standard that requires higher education institutions to pass the procedure of } \\
\text { external quality assurance on a regular basis, which ensures the principle of total quality } \\
\text { management (TQM) - continuous improvement }\end{array}$ \\
\hline
\end{tabular}

As shown by the comparative analysis, it is planned to expand the standards and guidelines for internal quality assurance with three new standards and guidelines. Thus, the provision enacted in 2003 in Berlin by the communique of the conference of higher education ministers of 33 European countries reading that the responsibility for the higher education quality assurance is primarily the responsibility of the educational institutions themselves remains relevant. Moreover, the responsibility of higher educational institutions increases.

Here are the main changes in the international standard ISO 9001:2015 "Quality Management System. 
Requirements":

1. Particular attention is paid to decision-making and planning of operations with account of risks. The internal audit procedure should take into account the risks.

2. Emphasis is made on obtaining the added value for the organization and its stakeholders.

3. The use of documentation has become more flexible.

4. The terminology has been changed. The term "products" has been replaced with the term "products and services," which includes all categories of processes output (hardware, services, software, and processed materials). The terms "document" and "records" have been replaced with the term "documented information."

5. The need for developing a quality guidance and mandatory documented procedures has been eliminated.

6. The term "outsourcing" has been replaced with the term "Externally provided goods and services."

7. The requirement to appoint a management representative for the quality management system. At the same time, the standard adds demands to leadership.

8. Also, quality objectives requirements have become stricter. Specification of "who," "what," and "when" is required.

9. Requirements for planning changes have been introduced.

10. The knowledge management has appeared.

11. An emphasis is laid on the achievement by processes of compliance with the requirements for products and services and customer satisfaction.

12. The management's analysis should consider the strategic directions of the company development (GOST ISO 9001-2011 "Quality Management Systems. Requirements"; ISO 9001:2008 "Quality management systems Requirements"; ISO 9001:2015 "Quality management systems - Requirements").

The changes introduced in the ISO 9001 standard make it "flexible" to apply. The documentation procedures have been facilitated-it is no longer required to develop additional documents only for the quality management systems: the quality guidance, essential documented procedures. Replacing the term "product" with the term "products and services" simplifies applying the standard in organizations that render services, particularly, higher educational institutions. Replacing the term "document" and "record" with the term "documented information" makes it easier to work with documents. Now you do not need to divide documentation, which often is "artificial," into documents and records, set different management procedures for them: the documented procedure "Control of documents" and the documented procedure "Control of records."

The year 2015 in the Russian system of quality assurance is the year of global changes.

The Government of the Russian Federation, while performing a preliminary analysis of the results of the implementation of the federal target program of education development for 2011-2015, stipulates that the measures for creating conditions for the development of the state and public assessment of the performance of educational institutions and the professional public accreditation by the end of 2015 will include a competition-based support for organizations that:

- develop and implement mechanisms for external expert assessment, professional public accreditation of educational programs;

- implement models and create conditions for the development and integration of the results of the state and public assessment of the quality of educational institutions activity.

Order of the Government of the Russian Federation dated 29.12.2014 \#2765-r approved the concept of the federal target program of education development for 2016-2020 (Order of the Government of the Russian Federation dated 29.12.2014 \#2765-r "On approval of the Concept of the federal target program for the development of education for 20162020"). The concept highlights the key points of education development and focuses on the education quality assurance. The need for the program as a tool for the effective implementation of the state policy in the sphere of education is determined by a number of factors of legal and system methodology nature, one of which is the relevance and appropriateness of the education system, which provides conditions and options for personal and professional development while assuring their quality.

As part of the task of formation of a popular education quality assessment system and educational outcomes, it is supposed to form a new attitude of students and educational institutions to the quality of education, procedures and mechanisms of its measurement and assessment. This goal will be achieved through the creation of a national-regional system of independent monitoring and assessment of education quality at all levels-from primary to higher-within the framework of the program. The system will be operated through a network of centers for education quality monitoring that will cover the entire territory of Russia and all levels of education. An appropriate target was set-"The share of regional education systems, in which assessment tools (based on international ones) have been developed and distributed for 
application for the purpose of intra-regional and inter-regional analysis and assessment of the quality of education in the total number of regional systems of education." The value of this indicator should reach $20 \%$ by 2020 .

Giving a preliminary assessment of the expected efficiency and effectiveness of the method of identification of ways to solve the specified problems proposed in the program, we have found that:

- within the framework of the measures for the development and dissemination in the vocational training system of the new technologies and forms of the education process organization by creating a regulatory basis, staff development, and analytical support, the implementation of the main requirements of the Bologna and Turin processes in all higher and secondary vocational education institutions is, inter alia, provided. This condition is supported by the target "The share of higher and vocational education institutions that have implemented the main requirements of the Bologna and Turin processes, respectively, in the total number of higher education institutions." The value of this indicator should reach $100 \%$ by 2020 ;

- within the framework of measures to improve the management quality in the system of higher and secondary vocational education through the development and dissemination of new models and technologies of management, the establishment and assurance of effective operation of state and public management with the participation of employers in all vocational education institutions is, inter alia, provided. The target indicator "The share of higher education institutions, which have implemented a system of monitoring of continuing education and professional development as well as employment and careers of graduates in the total number of higher education institutions" is provided. Its value should reach $100 \%$ by 2020 ;

- as part of the objective to form a popular system of education quality and educational outcomes assessment, the development of a quality assessment system in vocational and higher education will be, inter alia, implemented by supporting independent accreditation and quality assessment of educational programs, inclusion of the Russian Federation in international studies on the education quality. To this end, the participation of Russia in all significant (at least 10) international comparative studies of education quality is planned, as well as the development for regions and distribution to them of assessment tools (based on international ones) for an intra-regional and inter-regional analysis and assessment of the education quality and publication of a report on the comparative evaluation of the education quality in Russia based on the international research every two years.

A landmark event in the formation of a regulatory and methodological basis for the education quality assessment and assurance was the approval of Order of the Ministry of Education and Science of the Russian Federation dated 05.12.2014 \#1547 "On approval of the indicators characterizing the general criteria for assessing the quality of the educational activities of organizations engaged in educational activities" (Order of the Ministry of Education and Science dated 05.12.2014 \#1547). Four groups of indicators characterizing the overall criterion for assessing the quality of the educational activities of organizations engaged in educational activities has been approved, relating to: transparency and accessibility of information on organizations carrying out educational activities; comfortable environment, in which educational activities are performed; kindness, courtesy, competence of employees; satisfaction with the quality of the educational activities of the organizations.

In 2015 , the changes in the federal state educational standards of higher education, so-called FSES HE 3+, come into force. Their implementation in accordance with Article 11 of Federal Law 273-FZ provides state guarantees of the level and quality of education based on the unity of the mandatory requirements to the conditions of implementation of the basic education programs and the results of their implementation (Federal Law dated 29.12.2012 \#273-FZ).

Given the particular importance of the new standards and guidelines ESG ENQA, ISO, FSES, and the concept of the federal target program for the development of education, the provisions of these documents have been identified as the cross-cutting content areas of the system of education quality assurance of the Transbaikal State University, the model of which is shown in the figure (Fig. 1) (Starostina and Kazachek, 2013). 


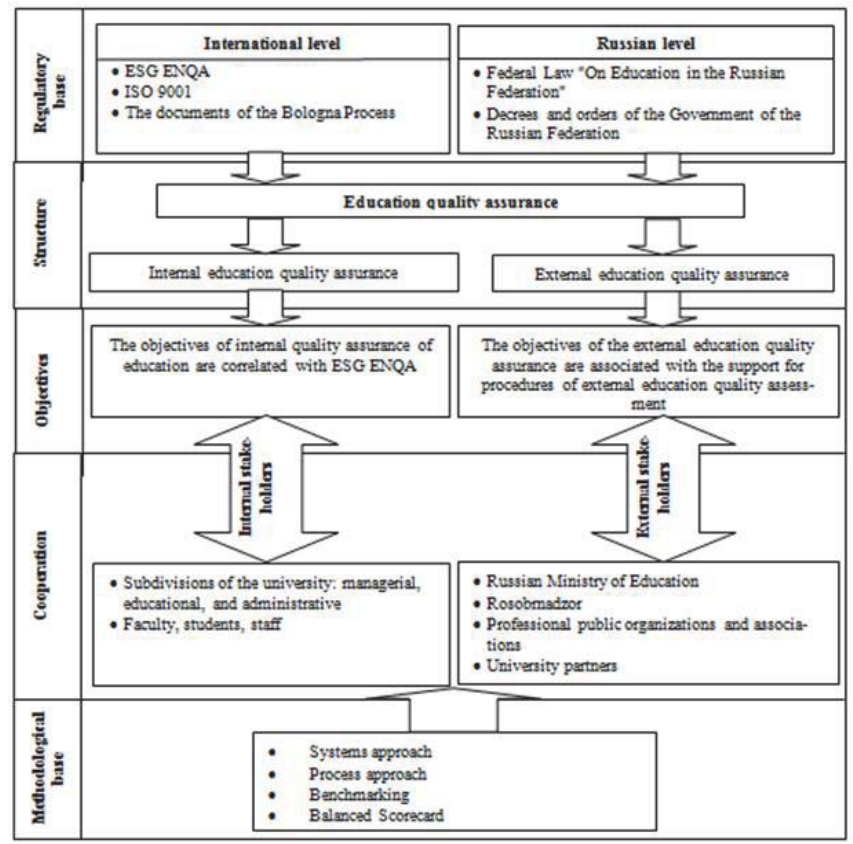

Figure 1. The system of education quality assurance.

The model uses the concept of "stakeholders," which is included in ESG ENQA and understood as all individuals within the university, including students and staff. External stakeholders are employers and partners of a higher educational institution (Standards and guidelines for quality assurance in the European Higher Education Area: revised edition, 2014). Focusing on the coming global changes in the system of quality assurance, the Transbaikal State University works under European standards, both mentioned in the 2005 standard, and planned for implementation in the 2015 standard. Here is a brief description of the university's work under several standards.

\subsection{The "Development and approval of programs" standard}

The process of developing and approving educational programs in the Transbaikal State University is regulated. The starting point in developing a program is the availability or absence of a professional standard relevant to the major or specialty.

If there is a professional standard, the program is developed in accordance with the guidelines of the Ministry of Education and Science of Russia (Letter of the Ministry of Education and Science of Russia dated 10.02.2015 \#05-308). First, the types of work and work functions are studied. Then, based on them, the list of additional professional competencies is defined.

In the absence of professional standards, the program development is preceded by the study of the types of work in the National Job Classificatory, the Uniform Wage-Rates and Skills Handbook, in sectoral orders and regulations relating to qualification requirements, and in educational standards of previous generations.

In determining the results of the study, the results of the research of the TUNING project-Tuning Educational Structures in Europe-are used. The project is aimed at rapprochement of educational institutions in countries that are members of the Bologna process through the application of the competence-based approach in higher education systems. According to this project, the learning outcomes are divided into two types:

- the minimum requirements determine the required level to pass a pass-fail exam;

- the learning expectations of the teacher from an "average" student.

In this regard, the learning outcomes are considered by their levels at the program development. 


\subsection{The "Information management" standard.}

The quality management system developed at the university has determined the system of internal monitoring of the management processes, as well as the main and auxiliary processes. The indicators, criteria, frequency of monitoring, and responsibility for the monitoring have been approved.

In accordance with Article 29 Part 2 Paragraph 3 of Federal Law dated 29.2.2012 \#273-FZ "On Education in the Russian Federation," the Transbaikal State University annually performs self-examination of its activities. To analyze the performance of the university and elaborate measures, they use a method of strategic planning-the SWOT-analysis. The following is the SWOT-analysis of the Transbaikal State University's activities, which was performed in 2014 (Table 2) (Report on the results of the self-examination of the activities of the FSBEl of HPE "Transbaikal State University").

Table 2. The SWOT-analysis of the Transbaikal State University activities

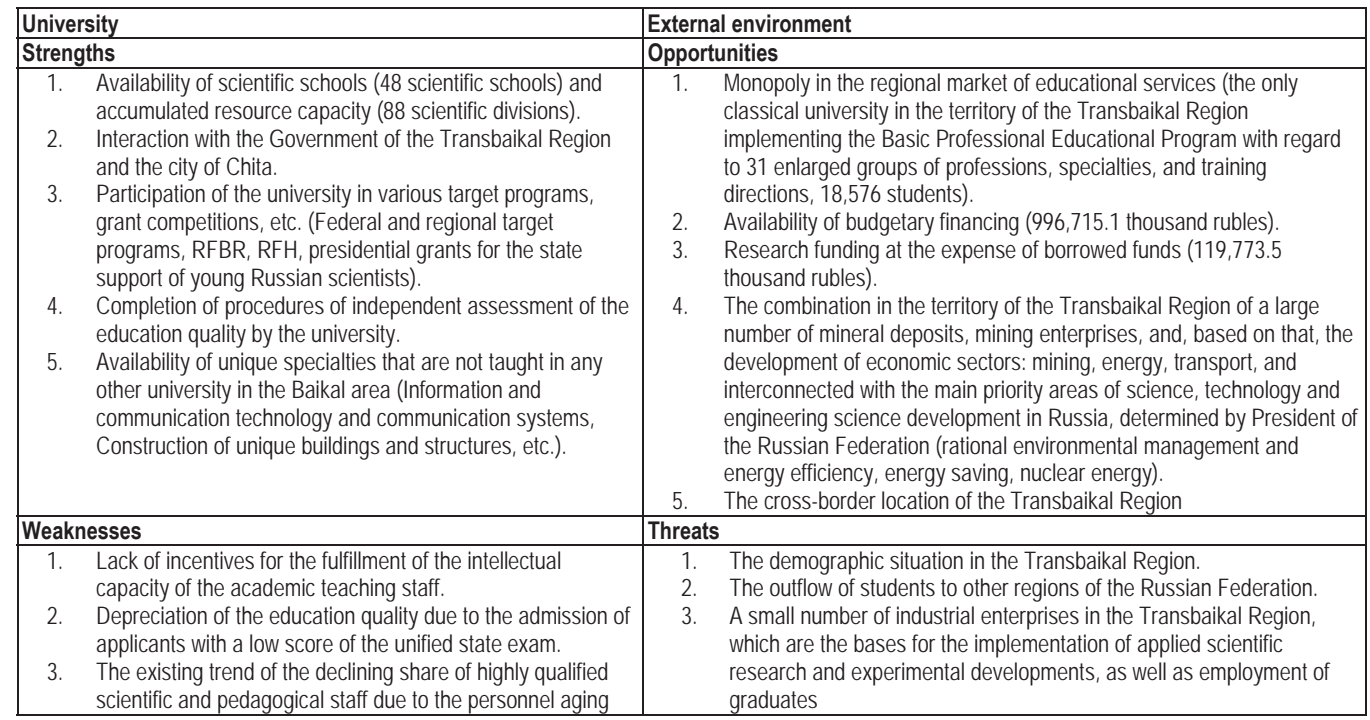

After the strengths and weaknesses, as well as the external opportunities and threats of the university have been defined, the implementation of the opportunities using the strengths, the neutralization of threats with the strengths, and the overcoming of weaknesses and threats using the favorable opportunities are carried out. This allows developing an action plan for the strategic development of the university (Table 3).

Table 3. Development of an action plan

\begin{tabular}{|c|c|}
\hline & List of events \\
\hline \multicolumn{2}{|l|}{ Implementation of opportunities using strengths } \\
\hline Strength & \multirow{4}{*}{$\begin{array}{l}\text { Establishment of the Collective Use Center of the Transbaikal State } \\
\text { University at the premises of the existing scientific units, followed by } \\
\text { isolation of clusters within the framework of the priority areas of } \\
\text { science, engineering, and technology in the Russian Federation } \\
\text { (environmental management, energy and energy efficiency, living } \\
\text { systems) }\end{array}$} \\
\hline Availability of scientific schools and accumulated resource capacity & \\
\hline Opportunity & \\
\hline $\begin{array}{l}\text { The combination in the territory of the Transbaikal Region of a large number of } \\
\text { mineral deposits, mining enterprises, and, based on that, the development of } \\
\text { economic sectors: mining, energy, transport, and interconnected with the main } \\
\text { priority areas of science, technology and engineering science development in } \\
\text { Russia, determined by President of the Russian Federation (rational } \\
\text { environmental management and energy efficiency, energy saving, nuclear } \\
\text { energy). }\end{array}$ & \\
\hline Strength & \multirow{4}{*}{$\begin{array}{l}\text { 1. Enrollment of foreign citizens in the university to the undergraduate, } \\
\text { specialist, graduate, and postgraduate programs. } \\
\text { 2. Participation of students in the organization and holding of the } \\
\text { International Student Spring of the Shanghai Cooperation }\end{array}$} \\
\hline Interaction with the Government of the Transbaikal Region and the city of Chita. & \\
\hline Opportunity & \\
\hline The cross-border location of the Transbaikal Region & \\
\hline
\end{tabular}




\begin{tabular}{|c|c|}
\hline & Organization countries as volunteers and key participants \\
\hline Strength & \multirow{4}{*}{$\begin{array}{l}\text { The intensification of the publication and inventive activity of the } \\
\text { scientific and pedagogical staff through the publication of the research } \\
\text { results in journals included in the Scopus and/or Web of Science } \\
\text { databases and having a high impact factor }\end{array}$} \\
\hline Participation of the university in various target programs, grant competitions, etc. & \\
\hline Opportunity & \\
\hline Research funding at the expense of raised funds & \\
\hline Strengths & \multirow{4}{*}{$\begin{array}{l}\text { Development of the basic professional educational applied bachelor } \\
\text { degree programs (according to FSES "3+") }\end{array}$} \\
\hline $\begin{array}{l}\text { 1. Availability of majors and specialties implemented only by this university in the } \\
\text { Baikal region. } \\
\text { 2. Completion of the procedures of independent evaluation of the education } \\
\text { quality by the university. }\end{array}$ & \\
\hline Opportunity & \\
\hline Budget financing & \\
\hline \multicolumn{2}{|l|}{ Neutralization of threats with strengths } \\
\hline Strength & \multirow{4}{*}{$\begin{array}{l}\text { Vocational and public accreditation of the basic professional } \\
\text { education programs }\end{array}$} \\
\hline $\begin{array}{l}\text { Completion of the procedures of independent assessment of the quality by the } \\
\text { university. }\end{array}$ & \\
\hline Threat & \\
\hline The outflow of students to other regions of the Russian Federation & \\
\hline Strength & \multirow{4}{*}{$\begin{array}{l}\text { Preparation of the basic professional educational programs to be } \\
\text { implemented in the network form }\end{array}$} \\
\hline $\begin{array}{l}\text { Availability of majors and specialties implemented only by this university in the } \\
\text { Baikal region }\end{array}$ & \\
\hline Threat & \\
\hline $\begin{array}{l}\text { A small number of industrial enterprises in the Transbaikal Region, which are the } \\
\text { bases for the implementation of applied scientific research and experimental } \\
\text { developments, as well as employment of graduates }\end{array}$ & \\
\hline Strength & \multirow{4}{*}{$\begin{array}{l}\text { Introduction of temporary research rates for persons working on their } \\
\text { doctoral theses for a period of } 1 \text { to } 3 \text { years }\end{array}$} \\
\hline Availability of scientific schools and accumulated resource capacity & \\
\hline Threat & \\
\hline $\begin{array}{l}\text { A small number of industrial enterprises in the Transbaikal Region, which are the } \\
\text { bases for the implementation of applied scientific research and experimental } \\
\text { developments, as well as employment of graduates }\end{array}$ & \\
\hline \multicolumn{2}{|l|}{ Use of the favorable opportunities to overcome weaknesses } \\
\hline Weakness & \multirow{4}{*}{$\begin{array}{l}\text { Adaptation of the mechanism of academic teaching staff stimulation } \\
\text { through the use of the effective contract principles }\end{array}$} \\
\hline $\begin{array}{l}\text { Lack of incentives for the fulfillment of the intellectual capacity of the academic } \\
\text { teaching staff }\end{array}$ & \\
\hline Opportunity & \\
\hline Budget financing & \\
\hline Weakness & \multirow{4}{*}{$\begin{array}{l}\text { Establishment of departments that provide practical training of } \\
\text { students at the premises of organizations performing the profile } \\
\text { activity that corresponds to the basic professional education program }\end{array}$} \\
\hline $\begin{array}{l}\text { The existing trend of the declining share of highly qualified scientific and } \\
\text { pedagogical staff due to the personnel aging }\end{array}$ & \\
\hline Opportunity & \\
\hline Monopoly in the regional market of educational services & \\
\hline \multicolumn{2}{|l|}{ The reducing adverse effects of the combination of weaknesses and threats } \\
\hline Weakness & \multirow{4}{*}{$\begin{array}{l}\text { 1. The inclusion of the website of the university (section "Admission } \\
\text { committee of the Transbaikal State University") in the top } 50 \text { websites } \\
\text { of the Russian universities by openness and accessibility. } \\
\text { 2. Development of programs to improve the quality of education in the } \\
\text { faculties }\end{array}$} \\
\hline $\begin{array}{l}\text { Depreciation of the education quality due to the admission of applicants with a } \\
\text { low score of the unified state exam. }\end{array}$ & \\
\hline Threat & \\
\hline $\begin{array}{l}\text { 1. The demographic situation in the Transbaikal Region. } \\
\text { 2. The outflow of students to other regions of the Russian Federation }\end{array}$ & \\
\hline
\end{tabular}

\subsection{The "Continuous monitoring and periodic evaluation of programs" standard.}

In 2014, a sociological study of the degree of satisfaction of stakeholders (students, teachers, employees, and employers) with the quality of the educational services was performed.

The standard values were reduced to five quality levels by all criteria, and each level of quality was assigned the following indices: very low (1), low (2), satisfactory (3), good (4), high (5).

For all criteria and indicators of satisfaction, a unified method of transferring it to the scale corresponding to the five given levels was developed. The study found that almost all indicators received a "good" level and only a few indicators were "satisfactory."

The study results were predetermined by a number of corrective and preventive actions.

The monitoring and periodic evaluation of educational programs are of particular importance in ensuring the quality of education. To this end, the educational program quality criteria as well as the sources of data for each criterion were developed (Table 4) (Blinov, Vinenko and Sergeev, 2013). 
Table 4. Educational program quality criteria

\begin{tabular}{|l|l|}
\hline Criteria & Data sources \\
\hline Compliance with the requirements of the society & $\begin{array}{l}\text { Students' performance according to the end-of-term exams' results, professional } \\
\text { public accreditation of educational programs, consumer satisfaction with the } \\
\text { quality of graduates training }\end{array}$ \\
\hline Focus on the labor market demands & \begin{tabular}{l} 
Percentage of employment \\
\hline Recognition by the scientific community
\end{tabular} \\
$\begin{array}{l}\text { Effectiveness of the research work of students and teachers (implementation of } \\
\text { research results in the educational process, inventive and publication activity, } \\
\text { etc.). }\end{array}$ \\
\hline Attractiveness for Russian students & Sociological study \\
\hline Capability of this program to achieve the set educational objectives & Sociological study \\
\hline Consistency and coherence of individual elements of the program & $\begin{array}{l}\text { Absence of teachers' and students' complaints on the procedure of the program } \\
\text { implementation }\end{array}$ \\
\hline
\end{tabular}

These criteria are included in the map of quality management system processes of the university, such as "Training activities," "Research activities," "Support for the students and graduates' employment," "Quality management." Monitoring by criteria is carried out within the framework of each process and by the internal audit service.

\subsection{The "Periodic external quality assurance procedures" standard}

The year 2014 was full of events and fruitful for the Transbaikal State University with regard to the completion of the procedures of external education quality assurance. Here are some of the results.

The university's education quality management system was certified by the Agency for Education Quality Monitoring and Career Development for compliance with ESQ ENQA (until 27.02.2017). The quality management system was also certified by the DQS-UL Group for compliance with ISO 9001:2008, GOST ISO 9001:2011 (until 19.01.2018).

The Agency for Higher Education Quality Assurance and Career Development provided independent external quality assessment of the following educational programs: Teacher education (the profile "Geographical Education"), Mining, Information and Communication Technologies and Communication Systems.

Educational programs: Applied Computer Science, Sociology, Teacher Education, Philology became the best innovative educational programs in Russia in 2014 (according to the official website of the project http://www.bestedu.ru).

The university expanded the work on completing the procedures of independent assessment of the education quality in accordance with Article 95 of Federal Law "On Education in the Russian Federation":

1. Regular participation in the federal online exam in the field of professional education. Each session involves up to $50 \%$ of full-time students.

2. Diagnostic testing of first-year students-in 2014 about 500 freshmen took part in it.

3. Participation in the federal online exam of bachelor degree graduates-in 2014 for 2 programs in an off-line mode; in 2015, the Transbaikal State University is the base site of the exam.

4. Annual student participation in online competitions.

\section{Conclusions and Suggestions}

We can state that the Transbaikal State University is ready for the upcoming regulatory and methodological changes in the education quality assurance field.

However, we should pay attention to the fact that the much needed by higher educational institutions external quality assurance procedures are rather costly. This is another obstacle to pass. However, in 2015, the Transbaikal State University plans to obtain public and professional accreditation for two engineering programs in the Association of Engineering Education of Russia according to the criteria agreed with ESG ENQA.

Legal and methodological changes in any system are not unexpected and momentary. These changes are determined by the development of the respective system and, as a rule, they are exposed to extended public discussion and adjustment before institutionalization. To ensure the compliance with regulatory and methodological changes at the time they come into effect, we suggest that the focus should be made on assurance of the following conditions:

- adherence of the top management to the innovation processes;

- inclusion of orientation to innovations in the "Code of corporate culture"; 
- informing the personnel of the organization about the document drafts, the enactment of which will ensure regulatory and methodological changes in certain activities;

- participation of the organization in discussing the introduced drafts of documents, proposal of corrections in them;

- organization of experimental sites in organizations for the proposed regulatory and methodological innovations that are discussed at the time of the experiment at the draft level;

- availability of qualified personnel ready to accept the changes and able to implement them. This determines the necessity of continuous development of the organization's personnel, particularly the management staff.

\section{Acknowledgements}

The study was performed within the framework of the project part of the state order in the field of scientific activity $(27.2479 .2014 / \mathrm{K})$.

\section{References}

Bagrova, N.V. (2014). Russian government policy and the formation of the system of quality assurance in education. Introduction of European standards and guidelines for quality assurance of education: Proceedings of the IX International Forum Experts' Guild (Motova, G.N., Ed., pp. 130-133). Moscow: Guild of Experts in the Field of Vocational Education.

Blinov, V.I., Vinenko, V.G., \& Sergeev, I.S. (2013). Methods of teaching in higher education: Study and practical guide (pp. 315). Moscow: Publishing House Yurayt.

Gorbashko, E.A., Gidrovich, S.R., \& Egorova, I.I. (2004). Assessment of the quality of education in the models of education quality management in higher education. Evaluation of the quality of education in Russian universities: experience and problems: Proceedings of the Intercollegiate Seminar, St. Petersburg, October 28, 2003. St. Petersburg: St. Petersburg State University.

GOST ISO 9001-2011 "Quality Management System. Requirements". Retrieved from: http://protect.gost.ru/document.aspx?control= $7 \& i d=179785$

Kazachek, N.A. (2012). Implementation of QMS in an educational institution. Inside Look. Metody Menedzhmenta Kachestva, 5, 14-19.

Kels, G. (1999). The process of self-esteem: a self-assessment guide for higher education (pp. 152). Moscow: Moscow Social and Scientific Foundation: the publishing house of the Center of Scientific and Learning Programs.

The criteria and procedure for professional public accreditation of educational programs in technical fields and professions. Approved by the Accreditation Council AEER, Minutes \#21 dated 19.11.2013. Retrieved from: http://aeer.ru/ru/form_and_docs.htm

Laushkina, N.S. (2014). Public accreditation as a tool for quality assurance. The Introduction of European standards and guidelines for quality assurance of education: Proceedings of the IX International Forum Experts' Guild (Motova, G.N., Ed., pp. 59-63). Moscow: Guild of Experts in the Field of Vocational Education.

Matveeva, O.A. (2014). The development of quality systems, which laid the basis for the concept of "Excellence": domestic and foreign experience. The Introduction of European standards and guidelines for quality assurance of education: Proceedings of the IX International Forum Experts' Guild (Motova, G.N., Ed., pp. 217-222). Moscow: Guild of Experts in the Field of Vocational Education.

Navodnov, V.G., Motova, G.N., \& Matveeva, O.A. (2013). Review of the principles of forming in-house systems of education quality assurance: training materials for the workshop (pp. 207). Yoshkar-Ola: Training and Consulting Center.

Report on the results of self-activity of the FSEI of HPE "Transbaikal State University". Retrieved from: http://zabgu.ru/files/html_ document/pdf_files/fixed/Rezul'taty'_2013/528718657.pdf

The letter of the Ministry of Education dated 02.10.2015 \#05-308 "On the direction of guidelines."

Pokholkov, Yu., Chuchalin, A., Boev, O., \& Mogilnitsky, S. (2004). Assurance and assessment of higher education quality. Vysshee Obrazovanie v Rossii, 2, 12-27.

Order of the Ministry of Education of the Russian Federation dated 05.12.2014 \#1547 "On approval of the indicators characterizing the general criteria for assessing the quality of the educational activities of organizations engaged in educational activities."

Order of the Government of the Russian Federation dated 29.12.2014 \#2765-r "On approval of the Concept of the federal target program of education development for 2016 - 2020."

Standards and guidelines for quality assurance in higher education in the European area (2008, pp. 58).Yoshkar-Ola: Accreditation in Education.

Standards and guidelines for quality assurance in higher education in the European area of higher education (draft, 2014, pp. 28). Yoshkar-Ola: National Center of Professional Accreditation.

Starostina, S.E., \& Kazachek, N.A. (2013). The system of education quality assurance. Standarty i Kachestvo, 10, 104-107.

Federal Law of 29.12.2012 \#273-FZ "On Education in the Russian Federation."

Yanov, V.V. (2014). Modern educational paradigm: system quality assurance and competence. Introduction of European standards and guidelines for quality assurance of education: Proceedings of the IX International Forum of Experts' Guild (Motova, G.N., Ed., 2014, pp. 260-263). Moscow: Guild of Experts in the Field of Vocational Education. 
Assad, A.A., \& Olian, J.D. (1995). Total quality and the academy: continuously improving the University of Maryland. In Academic Initiatives in Total Quality for Higher Education (Roberts, H.V., Ed., Vol. 1). ASQC, Milwaukee.

ISO 9001:2008 Quality management systems -- Requirements Retrieved from: http://www.iso.org/iso/ru/home.htm

ISO 9001:2015 Quality management systems -- Requirements (draft). Retrieved from: http://www.iso.org/iso/ru/home.htm Juran, J.M., \& Gryna, F.M. (1993). Quality Planning and Analyses: Inter. Editions (pp. 3-9). McGraw - Hill. Inc.

Quality Procedures in European Higher Education. ENQA Occasional Papers 5. European Network for Quality Assurance (2003, pp. 41). Helsinki. Retrieved from: http://www.enqa.eu/files/procedures.pdf

Standards and Guidelines for Quality Assurance in the European Higher Education Area. European Association for Quality Assurance in Higher Education and Culture. Helsinki, 2005. Retrieved from: http://www.bologna-bergen2005.no/Docs/00-Main_doc/050221_ ENQA_report.pdf 